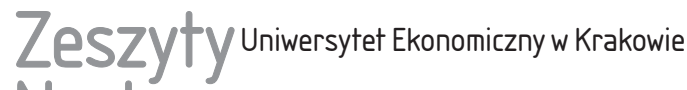 Naukowe
}

\section{Psychospołeczne aspekty pracy zdalnej. Wyniki badań przeprowadzonych $w$ trakcie trwania pandemii COVID-19}

\section{Streszczenie}

Cel: Celem artykułu jest zbadanie kontekstu psychospołecznego pracy zdalnej. W szczególności skoncentrowano się na zjawisku zaangażowania oraz niedogodnościach wywołanych przez niestandardową formę świadczenia pracy.

Metodyka badań: Badanie przeprowadzono na celowo dobranej próbie 201 pracowników, których praca stanowi tzw. digital output, co pozwala na świadczenie pracy zdalnie.

Wyniki badań: Przeprowadzone badanie wykazało, że jednostki, świadcząc pracę stacjonarnie, przejawiają wyższy poziom wigoru, poświęcenia i zaabsorbowania, niż wykonując pracę zdalnie. Za najistotniejszą niedogodność związaną z pracą zdalną uznano brak kontaktów towarzyskich.

Katarzyna Mierzejewska, Uniwersytet Ekonomiczny w Poznaniu, Instytut Zarządzania, Katedra Teorii Organizacji i Zarządzania, al. Niepodległości 10, 61-875 Poznań, e-mail: katarzyna.mierzejewska@ ue.poznan.pl, ORCID: https://orcid.org/0000-0001-7485-6483.

Michał Chomicki, Uniwersytet Ekonomiczny w Poznaniu, Instytut Zarządzania, Katedra Teorii Organizacji i Zarządzania, al. Niepodległości 10, 61-875 Poznań, e-mail: michal.chomicki@ ue.poznan.pl, ORCID: https://orcid.org/0000-0002-3918-7891.

Artykuł udostępniany na licencji Creative Commons Uznanie autorstwa-Użycie niekomercyjne-Bez utworów zależnych 4.0 (CC BY-NC-ND 4.0); https://creativecommons.org/licenses/ by-nc-nd/4.0/ 
Wnioski: W porównaniu z pracą świadczoną stacjonarnie długotrwałe świadczenie pracy zdalnie może negatywnie wpływać na zaangażowanie jednostek w pracę w trzech wymiarach - wigoru, poświęcenia i zaabsorbowania.

Wkład w rozwój dyscypliny: Otrzymane wyniki dają podstawy do dalszych badań dotyczących aspektów psychospołecznych w kontekście pracy zdalnej.

Słowa kluczowe: praca zdalna, pandemia COVID-19, zaangażowanie w pracę, aspekty psychospołeczne.

Klasyfikacja JEL: M12, J81.

\section{Wprowadzenie}

Rok 2020 zapisze się na kartach historii jako okres przełomowy, zmieniający zastane paradygmaty $\mathrm{w}$ relacjach międzyludzkich, ochronie zdrowia i higienie oraz globalnej gospodarce. W związku z wybuchem pandemii COVID-19, bo to jej konsekwencje mają i będą miały tak istotne znaczenie dla przyszłości, wiele przedsiębiorstw musiało zmierzyć się z sytuacją bezprecedensową - koniecznością utrzymania ciągłości prowadzonej działalności przy jednoczesnym zabezpieczeniu zdrowia i życia pracowników. Współczesne rozwiązania technologiczne potencjalnie pozwoliły na osiągnięcie pełnej zgodności między realizacją tych dwóch wymogów poprzez świadczenie pracy w formie pracy zdalnej. Ten niestandardowy sposób wykonywania pracy nie jest jednak bez znaczenia dla funkcjonowania jednostek i ich dobrostanu psychicznego. Stąd też celem niniejszego artykułu jest zbadanie kontekstu psychospołecznego tej nietypowej formy pracy. W szczególności skoncentrowano się na zjawisku zaangażowania oraz niedogodnościach wywołanych przez świadczenie pracy zdalnej.

\section{Praca zdalna jako istotny trend w rozwoju sposobów świadczenia pracy}

Praca zdalna jest zjawiskiem dobrze rozpoznawalnym zarówno w dyskursie naukowym, jak i praktyce gospodarczej. Jej korzenie sięgają lat 70. XX w., a dokładniej pierwszego kryzysu naftowego i związanej z nim ekstremalnej zmiany cen paliw oraz zagrożenia ekologicznego wywołanego nadmierną emisją spalin. Wydarzenia te skłoniły w 1973 r. amerykańskiego fizyka J. Nillesa do przeprowadzenia pierwszego eksperymentalnego projektu w obszarze pracy na odległość. Ta nowa elastyczna forma świadczenia pracy została spopularyzowana przez A. Tofflera (1980) w pracy wydanej w Polsce pt. Trzecia fala oraz przez futurologa F. Kinsmana w pracy The Telecommuters (Szluz 2013). 
W literaturze polskiej pojęcia pracy zdalnej (remote work) i telepracy (telework) często bywają ze sobą utożsamiane i stosowane wymiennie. Niektórzy badacze (Sęczkowska 2019, Dolot 2020) zwracają jednak uwagę, że telepraca dotyczy pracy świadczonej z domu na podstawie umowy o pracę, natomiast praca zdalna odnosi się do pracy realizowanej na zasadzie umowy o pracę umów cywilnoprawnych lub samozatrudnienia. Dodatkowo warto odwołać się do kodeksu pracy, który nie obejmuje uregulowań prawnych dotyczących pracy zdalnej, jedyną pokrewną formą świadczenia tego rodzaju pracy jest telepraca. W świetle prawa ,praca może być wykonywana regularnie poza zakładem pracy, z wykorzystaniem środków komunikacji elektronicznej w rozumieniu przepisów o świadczeniu usług drogą elektroniczną (telepraca)" (Kodeks pracy, art. $67^{5}$ par. 1). Stąd uważa się, że kryterium regularności i powtarzalności jest kluczowe dla rozróżnienia pracy zdalnej od telepracy (za: Dolot 2020, Wróbel i Jendza 2018). Terminem pracy zdalnej należałoby się zatem posługiwać wtedy, gdy jest ona wykonywana jedynie sporadycznie lub okresowo, tak jak ma to miejsce w przypadku pandemii COVID-19.

$\mathrm{W}$ języku potocznym praca zdalna zastępowana jest często angielskojęzycznym home office (domowe biuro), choć de facto jest tylko jedną z możliwych form wykonywania pracy na odległość (Szluz 2013). Ze względu na szeroki zakres omawianego pojęcia nie wypracowano jednej, a nawet kilku powszechnych definicji tej nietypowej formy pracy. Jedna $\mathrm{z}$ funkcjonujących $\mathrm{w}$ literaturze przedmiotu definicji określa pracę zdalną jako ,pracę realizowaną poza siedzibą pracodawcy, w zależności od formy: w miejscu zamieszkania pracownika lub w innym miejscu, czasem w ruchu, tj. w trakcie podróży (dosłownej, nie chodzi bowiem o delegację)" (Jeran 2016). Stąd praca zdalna nierzadko bywa (poza okresem pandemii) wykonywana poza domem, np. w kawiarniach, restauracjach, środkach transportu publicznego czy też w tzw. biurach coworkingowych. Kompleksowo pracę zdalną opisuje definicja E. Bąk (2006), według której pojęcie to odnosi się do każdej pracy umysłowej świadczonej poza standardowym miejscem pracy, której efekty przesyłane są do pracodawcy z wykorzystaniem technologii informatycznych i telekomunikacyjnych. Do cech charakteryzujących zarówno telepracę, jak i pracę zdalną zaliczyć można: wysoką elastyczność, możliwość świadczenia pracy z dowolnego miejsca na ziemi, konieczność dostępu do internetu, brak codziennych bezpośrednich kontaktów ze współpracownikami, zależność czasu pracy od potrzeb organizacji, na rzecz której świadczona jest praca, oraz od szybkości i efektywności działań pracownika, samodzielne regulowanie czasu pracy. Ostatni punkt jest jednak kwestią dyskusyjną. Wielokrotnie zdarza się bowiem, że pracownicy otrzymują zgodę na pracę zdalną lub telepracę, ale jednocześnie wymaga się od nich dyspozycyjności w tych samych godzinach co od osób pracujących stacjonarnie (Sęczkowska 2019). 
Rewolucja cyfrowa i związana z nią zmiana stylu życia oraz systemów wartości społeczeństw sprawiła, że praca zdalna już na długo przed pandemią COVID-19 cieszyła się z każdym rokiem coraz większą popularnością. Statystyki nie pozostawiają wątpliwości, że światowy trend popularności tej formy pracy ma charakter rosnący. W Stanach Zjednoczonych w okresie od 2005 do 2017 r. nastąpił wzrost tej formy świadczenia pracy o $44 \%$ wśród osób pracujących na odległość. W roku kończącym badanie ponad 7,9 mln Amerykanów pracowało wyłącznie z domu (Haven Life 2018).

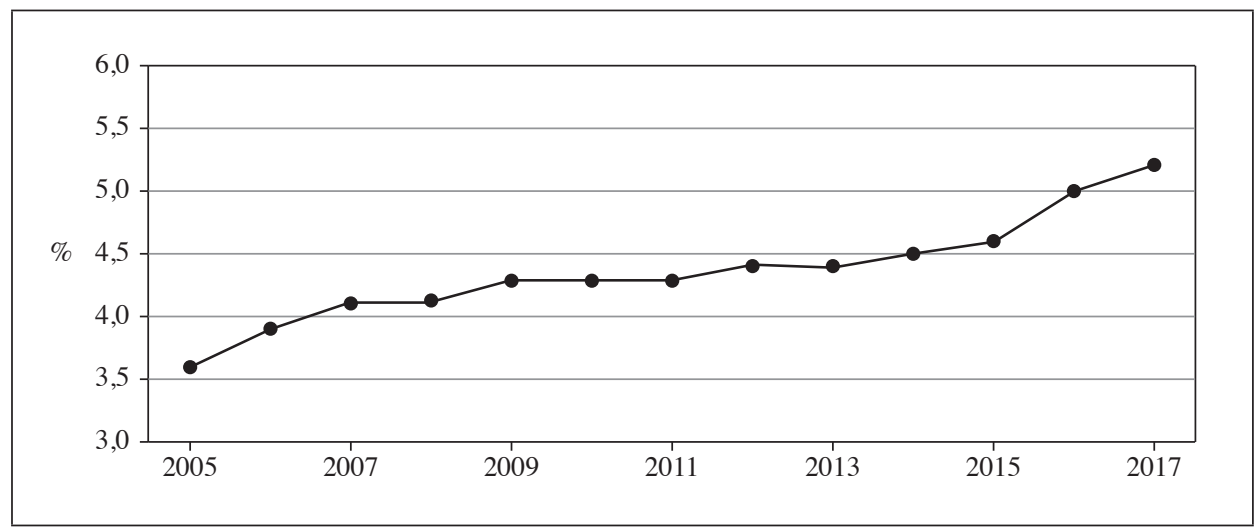

Rys. 1. Odsetek Amerykanów pracujących wyłącznie zdalnie w latach 2005-2017 Źródło: (Haven Life 2018).

Z kolei z raportu Brosix (2019) wynika, że aż 60\% Amerykanów miało możliwość pracy zdalnej. Zainteresowanie jednostek pracą na odległość prezentuje raport Owl Labs (2019), zgodnie z którym 42\% pracujących zdalnie badanych chciałoby zwiększyć dotychczasową częstotliwość tej formy pracy w ciągu najbliższych pięciu lat, natomiast połowa badanych pracujących dotychczas stacjonarnie chciałaby rozpocząć pracę zdalną. Tylko $19 \%$ badanych zadeklarowało, że nie chciałoby pracować poza tradycyjnej miejscem pracy. Co także ciekawe, badani pracujący zdalnie okazali się o $29 \%$ bardziej szczęśliwi niż pracownicy stacjonarni. Polska w porównaniu ze Stanami Zjednoczonymi i Europą Zachodnią pod względem osób pracujących zdalnie wypada zdecydowanie gorzej. Według raportu z badania przeprowadzonego przez Kantar TNS (2018) 70\% badanych twierdzi, że ich pracodawca w ogóle nie oferuje możliwości pracy zdalnej. Ponad połowa tej grupy $(51 \%)$ wyraziła chęć skorzystania z pracy zdalnej, gdyby taka możliwość istniała. Natomiast wszyscy badani mający alternatywę pracy zdalnej, niezależnie od wieku, korzystają z tej opcji, a 95\% z nich bardzo pozytywnie lub pozytywnie ocenia taką formę pracy. 
Do kluczowych czynników determinujących wzrost zainteresowania pracą zdalną można zaliczyć (Sęczkowska 2019, Szluz 2013):

- po stronie pracownika: chęć większej elastyczności pracy (elastyczność miejsca pobytu, dostosowanie czasu i rytmu pracy do własnych możliwości), chęć ograniczenia dojazdów do pracy i związanych z tym kosztów ekonomicznych i psychologicznych, możliwość godzenia pracy zawodowej z życiem prywatnym i rodziną, chęć pracy w przyjaznych warunkach (architektura i wyposażenie wnętrza, dowolność ubioru), chęć uniknięcia współpracowników, względem których odczuwa się antypatię;

- po stronie pracodawcy: podniesienie konkurencyjności, dostosowanie się do trendów światowych i potrzeb młodego pokolenia, obniżenie kosztów organizacji pracy, minimalizacja absencji pracowników, chęć pozyskania wysoko wykwalifikowanych specjalistów do realizacji projektów.

Z kolei wśród najistotniejszych czynników budzących obawy wobec pracy zdalnej można wyróżnić (Jeran 2016, Szluz 2013):

- po stronie pracodawcy: ograniczoną kontrolę nad pracownikami zdalnymi, obawę przed zmniejszeniem identyfikacji pracownika z organizacją, pogorszenie relacji interpersonalnych z pracownikami zdalnymi, obawę przed utratą danych, możliwość wystąpienia awarii sprzętu lub słabego łącza internetowego;

- po stronie pracownika: poczucie odizolowania i osłabienia więzi międzyludzkich, zanikanie granicy między życiem zawodowym a osobistym, obawę przed obniżeniem motywacji oraz spadkiem produktywności ze względu na czynniki rozpraszające w domowym otoczeniu, mniejszą możliwość awansu i uczestnictwa w szkoleniach w porównaniu z pracującymi stacjonarnie, niewystarczający dostęp do informacji.

Powyższe obawy po stronie pracownika stanowią swoistego rodzaju utrudnienia, z którymi borykają się jednostki świadczące pracę zdalną. Większość z wymienionych obaw dotyczy psychospołecznego aspektu funkcjonowania pracowników i tworzy ciekawe pole do badania czynników wiążących się z niedogodnościami świadczenia pracy zdalnej.

Wybuch pandemii COVID-19 doprowadził do zmian niemalże na każdej płaszczyźnie codziennego funkcjonowania jednostek. Diametralnie zmienił się paradygmat świadczenia pracy. Każda zaś zmiana, w szczególności duża i nieoczekiwana, generuje negatywne emocje i wiąże się ze wzrostem poziomu stresu, nie pozostając bez znaczenia dla zdrowia psychicznego, motywacji, satysfakcji, a także zaangażowania pracowników (Oreg, Vakola i Armenakis 2011). Oprócz opisania wspomnianych niedogodności świadczenia pracy zdalnej, w niniejszym opracowaniu skoncentrowano się na zjawisku zaangażowania w pracę, któremu przypisuje się niemałe znaczenie w kontekście skuteczności funkcjonowania przedsiębiorstw i ich rozwoju (Łochnicka 2015). 
Dla potrzeb artykułu zaangażowanie w pracę (work engagement), zgodnie z koncepcją autorstwa W. Schaufeliego (Schuafeli i in. 2002), zdefiniowano jako pozytywny, satysfakcjonujący i odnoszący się do pracy stan umysłu, który wyrażony jest w trzech wymiarach: wigoru (vigor) podczas wykonywanej pracy, poświęcenia się pracy (dedication) oraz zaabsorbowania pracą (absorption). Wigor określa poziom energii i odporności psychicznej podczas wykonywanej pracy. Poświęcenie się pracy, nazwane także oddaniem się pracy, wyraża stopnień utożsamiania się ze swoją pracą oraz przypisywania jej wartości. Zaabsorbowanie pracą definiuje stopień koncentracji na pracy, zanurzenia się w niej, czy wręcz pochłonięcia przez nią.

Poznanie psychospołecznych aspektów świadczenia pracy zdalnej w długim okresie, w szczególności identyfikacja poziomu zaangażowania w pracę oraz istotnych niedogodności związanych z tą niestandardową formą pracy, pozwoli zwiększyć świadomość pracodawców w zakresie konsekwencji i zagrożeń powstałych w wyniku wykonywania pracy zdalnej. W dalszej kolejności umożliwi pracodawcom podjęcie środków przeciwdziałających ewentualnym negatywnym skutkom tej formy pracy i efektywniejsze wykorzystanie swojego najcenniejszego zasobu, jakim jest kapitał ludzki, w nowej, postpandemicznej rzeczywistości.

\section{Wyniki postepowania badawczego w badaniach nad psychospołecznymi aspektami wykonywania pracy zdalnej}

Badanie zostało przeprowadzone na celowo dobranej próbie pracowników, których praca stanowi tzw. digital output, co pozwala na świadczenie pracy zdalnie. Przeprowadzono je techniką CAWI (computer assisted Web interview), polegającą na rozesłaniu linków z dostępem do kwestionariusza ankiety i zebraniu danych w formie elektronicznej. W ankiecie wzięło udział 215 osób, z czego pracę zdalną w okresie pandemii świadczyło 201 osób (przedmiot analizy zawartej w niniejszym opracowaniu), czyli ponad $93 \%$ adresatów. Świadczy to o wysokiej zdolności pracodawców do wykorzystania tej formy pracy w celu zwalczania sytuacji kryzysowej w przedsiębiorstwie. Postępowanie badawcze charakteryzuje się pewnymi ograniczenia wynikającymi z subiektywizmu oceny sytuacji przez pracowników oraz możliwości niedysponowania pełnią wiedzy w badanych obszarach. W badaniu wzięło udział 113 kobiet (56\%) oraz 88 mężczyzn (44\%). Na rys. 2 przedstawiono rozkład respondentów ze względu na częstotliwość wykonywania pracy zdalnej przed wybuchem pandemii.

Analizując dane przedstawione na rysunku można zauważyć, że ponad $42 \%$ badanych ma wpisane świadczenie pracy zdalnej w treść stosunku pracy jako podstawową lub równorzędną formę świadczenia pracy (świadczenie pracy zdalnie w sposób ciągły oraz co najmniej jeden dzień w tygodniu). Niecałe $41 \%$ 
respondentów świadczyło pracę zdalnie mniej regularnie - można wnioskować, że nie był to element stosunku pracy, a raczej element systemu motywacyjnego pracodawcy, który może arbitralnie zadecydować o formie świadczenia pracy na wniosek pracownika. Prawie 17\% badanych nie świadczyło pracy zdalnej w ogóle.

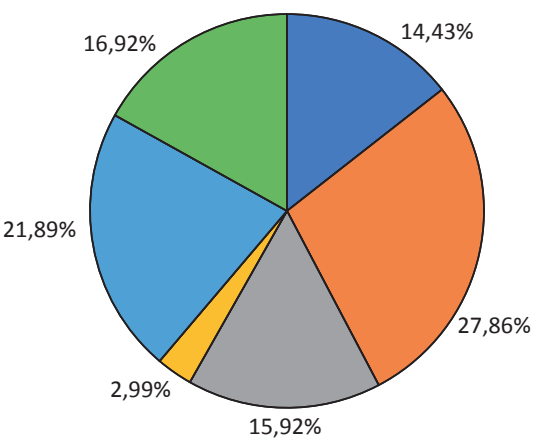

stale

$\square$ co najmniej 1 raz w tygodniu

$\square$ co najmniej 1 raz w miesiącu

$\square$ co najmniej 1 raz na kwartał

$\square$ sporadycznie

$\square$ nigdy

Rys. 2. Częstotliwość wykonywania przez respondentów pracy zdalnej przed pandemią COVID-19

Źródło: opracowanie własne na podstawie przeprowadzonych badań.

Ponad 69\% pracodawców respondentów stanowiły przedsiębiorstwa bez udziału kapitału zagranicznego, a pozostałe $31 \%$ - przedsiębiorstwa z udziałem kapitału tego typu. Ponad 79\% pracodawców respondentów stanowiły przedsiębiorstwa prywatne, a niecałe $29 \%$ - przedsiębiorstwa publiczne. Na rys. 3 przedstawiono strukturę respondentów według wielkości pracodawcy.

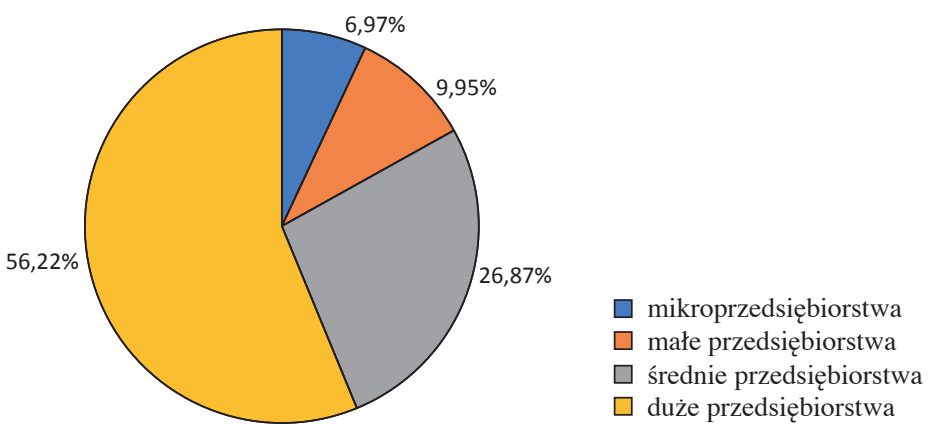

Rys. 3. Wielkość organizacji pracodawców respondentów

Źródło: opracowanie własne na podstawie przeprowadzonych badań. 
Zdecydowanie najwięcej respondentów pracowało dla dużych przedsiębiorstw (ponad 56\%), a najmniej - dla mikroprzedsiębiorstw (niecałe 7\%).

Na potrzeby narzędzia badawczego - kwestionariusza ankietowego - przyjęto 5-stopniową skalę R. Likerta: 1 - zdecydowanie się nie zgadzam, 2 - raczej się nie zgadzam, 3 - nie mam zdania, 4 - raczej się zgadzam, 5 - zdecydowanie się zgadzam. Mając świadomość ograniczeń narzuconych przez przyjęta skalę, którą ze statystycznego punktu odniesienia należy uznać za skalę porządkową, postanowiono zaprezentować podstawowe statystyki opisowe dla celów syntetycznego ukazania tendencji występujących w całej próbie badanych.

Odwołując się do trójczynnikowej koncepcji zaangażowania w pracę W. Schaufeliego (Schuafeli i in. 2002), przeprowadzono badania nad różnicami w zaangażowaniu w pracę w zależności od formy jej świadczenia.

Tabela 1 prezentuje statystyki dotyczące oceny wspomnianych trzech wymiarów zaangażowania według podziału ze względu na formę świadczenia pracy.

Tabela 1. Podstawowe statystyki dotyczące oceny trzech wymiarów zaangażowania (wigor, poświęcenie, zaabsorbowanie) według podziału ze względu na formę świadczenia pracy

\begin{tabular}{|l|c|c|c|}
\hline \multicolumn{1}{|c|}{ Wyszczególnienie } & Średnia & $\begin{array}{c}\text { Odchylenie } \\
\text { standardowe }\end{array}$ & Dominanta \\
\hline $\begin{array}{l}\text { Moja praca świadczona stacjonarnie sprawia, że czuję } \\
\text { się pełen energii (ocena wigoru) }\end{array}$ & 3,35 & 1,15 & 4 \\
\hline $\begin{array}{l}\text { Potrafię się poświęcić dla pracy, wykonując ją stacjo- } \\
\text { narnie (ocena poświęcenia) }\end{array}$ & 3,51 & 1,15 & 4 \\
\hline $\begin{array}{l}\text { Gdy wykonuję pracę stacjonarnie, trudno mnie od niej } \\
\text { odciągnąć (ocena zaabsorbowania) }\end{array}$ & 3,19 & 1,10 & 3 \\
\hline $\begin{array}{l}\text { Moja praca świadczona zdalnie sprawia, że czuję się } \\
\text { pełen energii (ocena wigoru) }\end{array}$ & 2,72 & 1,25 & 3 \\
\hline $\begin{array}{l}\text { Potrafię się poświęcić dla pracy, wykonując ją zdalnie } \\
\text { (ocena poświęcenia) }\end{array}$ & 3,00 & 1,22 & 3 \\
\hline $\begin{array}{l}\text { Gdy wykonuję pracę zdalnie, trudno mnie od niej } \\
\text { odciągnąć (ocena zaabsorbowania) }\end{array}$ & 2,84 & 1,22 & 3 \\
\hline
\end{tabular}

Źródło: opracowanie własne na podstawie przeprowadzonych badań.

Analizując dane zawarte w tabeli 1, można zauważyć, że respondenci częściej wskazywali, iż ich praca świadczona stacjonarnie charakteryzuje się wyższym poziomem wigoru, poświęcenia i zaabsorbowania niż w przypadku jej świadczenia zdalnie. Dane te zostały przedstawione na rys. 4 . Zestawienie tych wartości pozwala stwierdzić, że wśród respondentów występuje tendencja do oceniania pracy stacjonarnej jako formy świadczenia bardziej angażującej w każdym ocenianym wymiarze. 


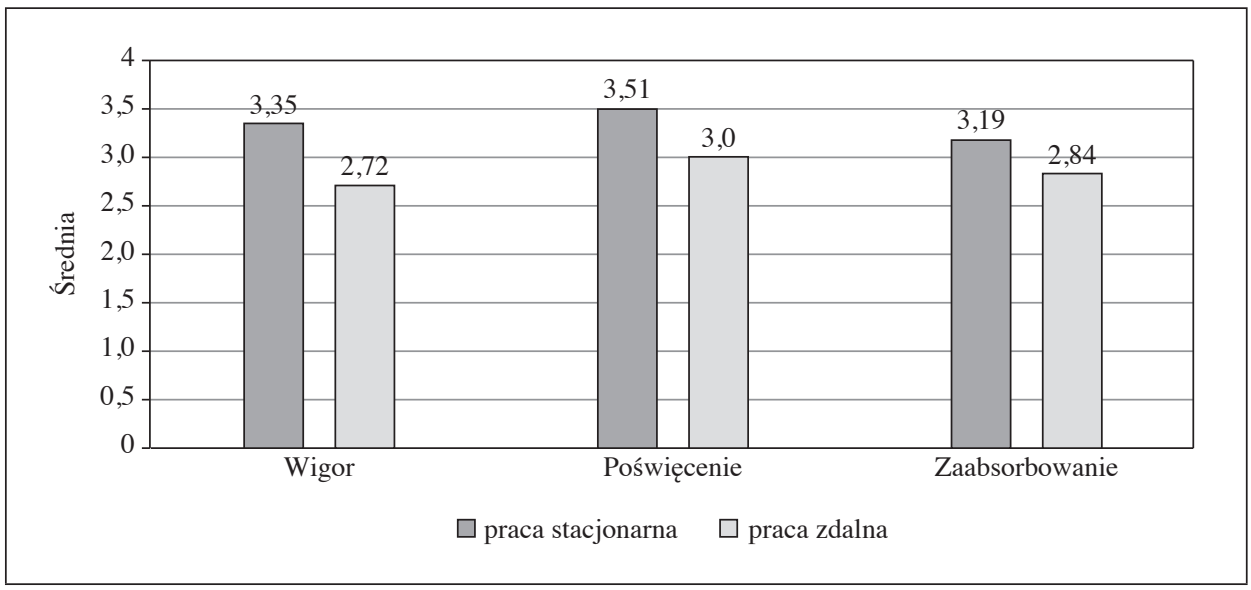

Rys. 4. Zestawienie średnich ocen dla poszczególnych składowych zaangażowania (wigoru, poświęcenia i zaabsorbowania) w zależności od formy świadczenia pracy Źródło: opracowanie własne na podstawie przeprowadzonych badań.

Należy też zwrócić uwagę na zestawienie różnic między ocenami trzech wymiarów zaangażowania w kontekście form świadczenia pracy. Na rys. 5 przedstawiono rozkłady tych różnic między ocenami w poszczególnych wymiarach.

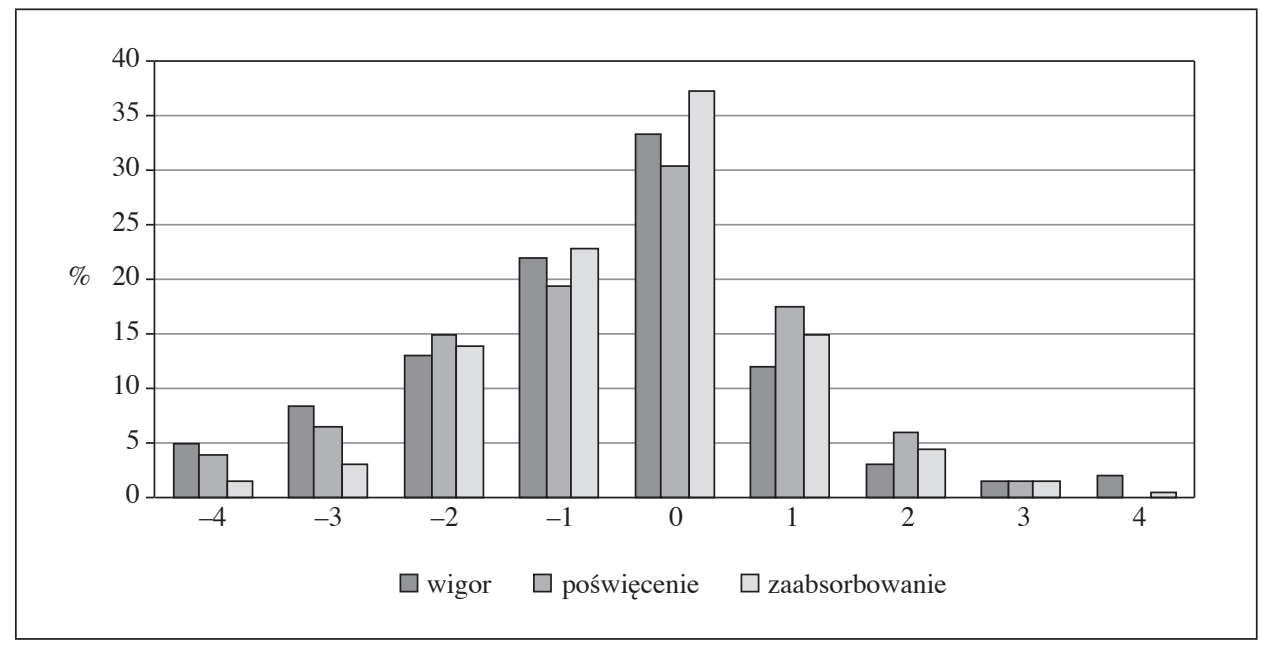

Rys. 5. Zestawienie rozkładów różnic w ocenach poszczególnych składowych zaangażowania (wigoru, poświęcenia i zaabsorbowania) między pracą świadczoną zdalnie a pracą świadczoną stacjonarnie

Źródło: opracowanie własne na podstawie przeprowadzonych badań. 
Analizując dane przedstawione na rys. 5, można zauważyć, że rozkłady różnic mają charakter lewoskośny, co oznacza, że przeważająca część respondentów oceniała wigor, poświęcenie i zaabsorbowanie wyżej w przypadku pracy stacjonarnej.

Tabela 2 prezentuje podstawowe statystyki dotyczące oceny niedogodności występujących w trakcie pracy zdalnej.

Tabela 2. Podstawowe statystyki dotyczące oceny poszczególnych niedogodności występujących w procesie świadczenia pracy w formie zdalnej

\begin{tabular}{|l|c|c|c|}
\hline \multicolumn{1}{|c|}{ Wyszczególnienie } & Średnia & $\begin{array}{c}\text { Odchylenie } \\
\text { standardowe }\end{array}$ & Dominanta \\
\hline Brak kontaktów towarzyskich & 3,50 & 1,26 & 4 \\
\hline Brak bezpośredniej komunikacji i współpracy & 3,22 & 1,34 & 4 \\
\hline Rozproszenie przez środowisko domowe & 3,08 & 1,41 & 4 \\
\hline Spadek motywacji & 2,54 & 1,30 & 1 \\
\hline $\begin{array}{l}\text { Zacieranie się granic między pracą a życiem } \\
\text { prywatnym }\end{array}$ & 3,17 & 1,44 & 5 \\
\hline
\end{tabular}

Źródło: opracowanie własne na podstawie przeprowadzonych badań.

Można zauważyć, że największą niedogodnością w pracy zdalnej wskazaną przez respondentów był brak kontaktów towarzyskich, a najmniejszą - spadek motywacji. Obserwacja ta wydaje się interesująca w szczególności z zestawieniem jej z wynikami oceny trzech wymiarów zaangażowania, będącego jedną z pochodnych motywacji. Respondenci wskazali, że spadek motywacji wpływał w najmniejszym stopniu z przedstawionych niedogodności na komfort ich pracy $\mathrm{w}$ formie zdalnej, przy czym sam spadek zaangażowania był zauważalny zwłaszcza w wymiarze wigoru. Dane dotyczące oceny niedogodności przedstawiono na rys. 6.

W dalszej części niniejszego opracowania przeprowadzono analizę odpowiedzi w zależności od cech respondentów i ich pracodawców dla statystycznie istotnych zależności na podstawie testów niezależności chi-kwadrat.

Na rys. 7 przedstawiono rozkłady odpowiedzi dotyczących braku bezpośredniej komunikacji i współpracy jako istotnej niedogodności w procesie świadczenia pracy zdalnie $\mathrm{w}$ zależności od własności przedsiębiorstwa pracodawcy (przedsiębiorstwa prywatne - przedsiębiorstwa publiczne). Wartość testu chi-kwadrat wyniosła 17,02. Wartość współczynnika kontyngencji C Pearsona wyniosła 0,28 (przy phi Yule'a oraz V Craméra wynoszących 0,29), co świadczy o umiarkowanej zależności między własnością przedsiębiorstwa a udzielonymi odpowiedziami. 


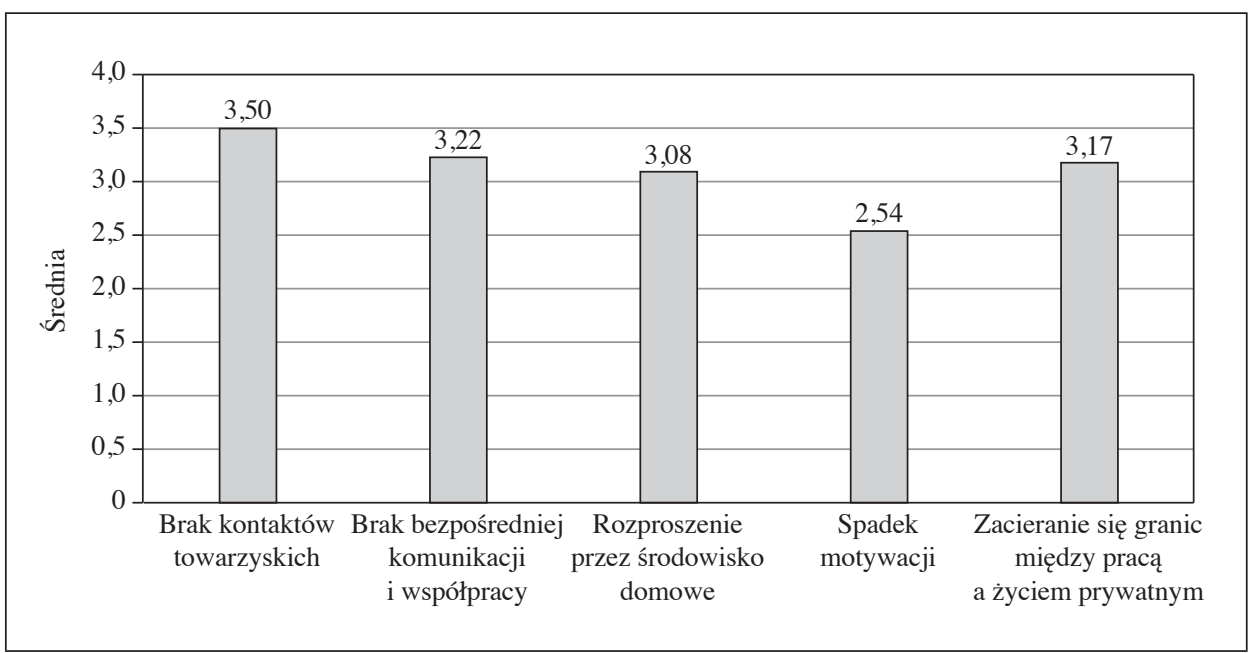

Rys. 6. Zestawienie średnich ocen niedogodności w pracy zdalnej

Źródło: opracowanie własne na podstawie przeprowadzonych badań.

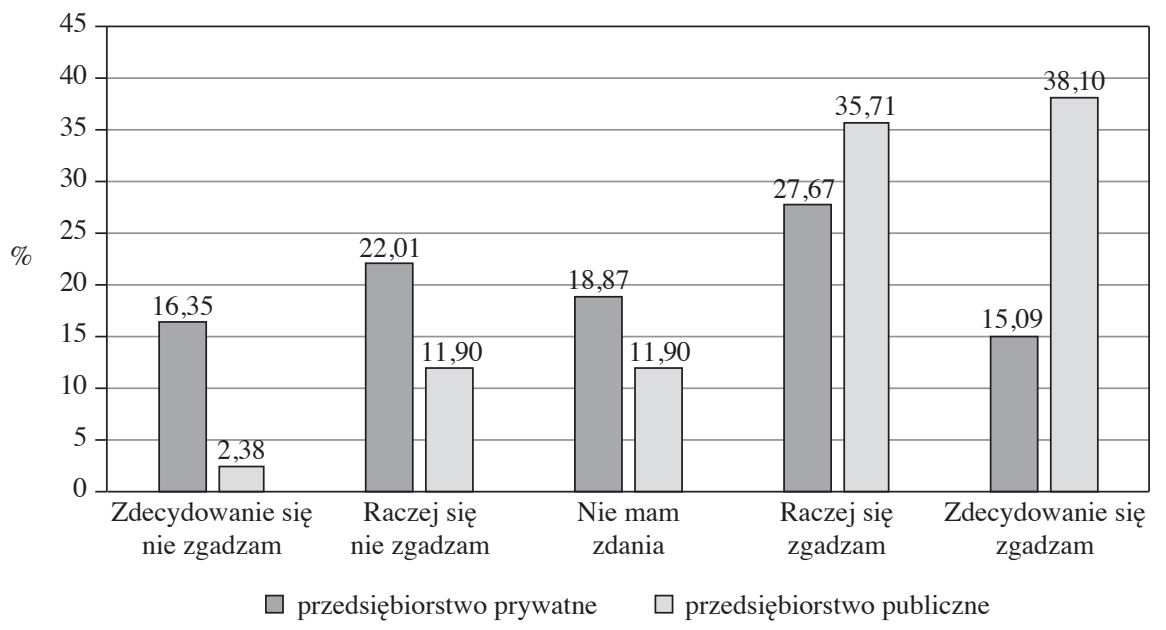

Rys. 7. Brak bezpośredniej komunikacji i współpracy jako istotna niedogodność w świadczeniu pracy zdalnie w zależności od własności organizacji (przedsiębiorstwo prywatne - przedsiębiorstwo publiczne)

Źródło: opracowanie własne na podstawie przeprowadzonych badań. 
Analiza danych przedstawionych na rys. 7 pozwala stwierdzić, że pracownicy przedsiębiorstw publicznych zdecydowanie częściej odczuwali niedogodność w trakcie świadczenia pracy zdalnie z powodu braku bezpośredniej komunikacji i współpracy (prawie 74\% wskazań) niż pracownicy przedsiębiorstw prywatnych (niecałe 43\% wskazań w tej grupie). Opisywaną obserwację można uzasadniać wykorzystaniem bardziej zaawansowanych rozwiązań komunikacyjnych przez przedsiębiorstwa prywatne, które lepiej zastępowały bezpośrednie relacje. Ponadto wpływ na zaistniałą sytuację mogła mieć efektywniejsza architektura procesów oraz związana z nią kultura organizacyjna nastawiona na sprawne realizowanie zadań.

\section{Podsumowanie}

Obiektywna dla wszystkich uczestników życia gospodarczego sytuacja kryzysowa wynikająca z pandemii COVID-19 stanowi bezprecedensowe wyzwanie nie tylko dla pracodawców, ale także dla pracowników. Jej konsekwencje wymagają zwinnych zachowań oraz wykorzystania dynamicznych zdolności w celu dostosowania się do nowych uwarunkowań, czyli sprawnego przystosowania się do zmieniających warunków otoczenia poprzez rekonfigurację portfela zasobów, w szczególności dzięki zastosowaniu systemów teleinformatycznych. Jednym z przykładów takiego działania jest wprowadzenie przez pracodawców zalecenia bądź też nakazu (w zależności od etapu rozwoju pandemii) pracy zdalnej w okresie pandemii COVID-19.

Analizując wyniki przeprowadzonych badań, należy stwierdzić, że na ogół respondenci niżej oceniają kwestie związane z zaangażowaniem we wszystkich trzech badanych obszarach - wigoru, poświęcenia, zaabsorbowania - w przypadku pracy zdalnej w porównaniu z pracą świadczoną stacjonarnie. Respondenci wskazywali na brak kontaktów towarzyskich jako najistotniejszą niedogodność związaną z pracą zdalną, najrzadziej wskazywali na spadek motywacji.

Istotne różnice zostały zaobserwowane, jeżeli chodzi o podział respondentów ze względu na kryteria określające ich pracodawców - własność przedsiębiorstwa (w podziale prywatne - publiczne) w ocenie niedogodności związanej z brakiem bezpośredniej komunikacji i współpracy. Niedogodność ta miała zdecydowanie większe znaczenie dla pracowników przedsiębiorstw państwowych.

Wyniki przeprowadzonych badań literaturowych i empirycznych, zarówno przed wybuchem pandemii (zob. Haven Life 2018), jak i już w czasie jej trwania (zob. Antal 2020), dają podstawę do prognozy, że praca zdalna jako forma świadczenia pracy będzie w dalszym ciągu zwiększać swoją popularność. Co więcej, tempo wzrostu jej popularności niewątpliwie przyspieszy dzięki pandemii 
COVID-19, która zadziałała jak katalizator - intensyfikując ten proces i jednocześnie potwierdzając efektywność pracy zdalnej jako równorzędnej formy świadczenia pracy. Można też przypuszczać, że wraz z rozwojem narzędzi teleinformatycznych w przyszłości praca zdalna będzie stanowiła alternatywę dla pracy bezpośredniej, o której decydować będzie pracownik, a nie pracodawca. W konsekwencji może to uczynić pracę zdalną dominującym sposobem świadczenia pracy na stanowiskach, których produkt ma charakter niematerialny i nie jest związany z koniecznością obecności w konkretnym miejscu (digital output). Biorąc jednak pod uwagę psychospołeczne konsekwencje długotrwałego świadczenia pracy zdalnej, pracodawcy powinni przywiązywać większą wagę do zapewnienia psychicznego dobrostanu pracowników. Na podstawie analiz i wyciągniętych wniosków należy stwierdzić, że w szczególności powinni wspierać budowanie, utrzymywanie i rozwijanie relacji interpersonalnych oraz kontaktów towarzyskich swoich pracowników.

\section{Literatura}

Antal (2020), Raport: Elastyczność specjalistów i menedżerów w dobie zmian, https:// antal.pl/wiedza/raport/elastycznosc-specjalistow-i-menedzerow-w-dobie-zmiany (data dostępu: 26.10.2020).

Bąk E. (2006), Elastyczne formy zatrudnienia, C.H. Beck, Warszawa.

Brosix (2019), Working Remotly, https://www.brosix.com/files/docs/Working-RemotelyStatistics-and-Data.pdf (data dostępu: 10.05.2020).

Dolot A. (2020), Wpływ pandemii COVID-19 na prace zdalnq - perspektywa pracownika, ,E-mentor”, nr 1(83), https://doi.org/10.15219/em83.1456.

Haven Life (2018), The Cities with the Most Remote Workers, https://havenlife.com/blog/ cities-with-the-most-remote-workers/ (data dostępu: 10.05.2020).

Jeran A. (2016), Praca zdalna jako źródło problemów realizacji funkcji pracy, „Opuscula Sociologica", nr 2, https://doi.org/10.18276/os.2016.2-04.

Kantar TNS (2018), Raport: The Remote Future. Rynek pracy zdalnej a oczekiwania pracowników, Edycja Polska, http://branden.biz/wp-content/uploads/2018/06/The-RemoteRnek-pracy-zdanej.pdf (data dostępu: 12.05.2020).

Łochnicka D. (2015), Zaangażowanie pracownicze jako determinanta rozwoju organizacji, „Studia Prawno-Ekonomiczne”, t. XCIV.

Oreg S., Vakola M., Armenakis A. (2011), Change Recipients' Reactions to Organizational Change: A 60-Year Review of Quantitative Studies, ,The Journal of Applied Behavioral Science", vol. 47, nr 4, https://doi.org/10.1177/0021886310396550.

Owl Labs (2019), State of Remote Report, https://www.owllabs.com/hubfs/Owl\%20 Labs\%202019\%20State\%20of\%20Remote\%20Work\%20Report\%20PDF.pdf (data dostępu: 10.05.2020).

Schaufeli W.B., Salanova M., Gonzalez-Roma V., Bakker A.B. (2002), The Measurement of Engagement and Burnout: A Two Sample Confirmatory Factor Analytic Approach, „Journal of Happiness Studies”, nr 3, https://doi.org/10.1023/A:1015630930326. 
Sęczkowska K. (2019), Konsekwencje psychospołeczne pracy zdalnej, „Problemy Nauk Humanistycznych i Społecznych. Teoria i Praktyka", nr 2.

Szluz B. (2013), Telepraca - nowoczesna elastyczna forma zatrudnienia i organizacji pracy. Szansa czy zagrożenie?, „Modern Management Review”, vol. XVIII, nr 20(4), https://doi.org/10.7862/rz.2013.mmr.59.

Toffler A. (1980), The Third Wave, William Morrow, New York.

Wróbel P., Jendza D. (2018), Telepraca - regulacje prawne a praktyka rynku pracy, „E-mentor”, nr 3(75), https://doi.org/10.15219/em75.1363.

\section{Psycho-Social Aspects of Remote Work: The Results of Research Carried Out during the COVID-19 Pandemic}

(Abstract)

Objective: The aim of the article is to explore the psychosocial context of remote work. There is a particular focus on engagement and the inconvenience caused by a non-standard work format.

Research Design \& Methods: The study was conducted on a sample of 201 employees engaged in digital output and able work remotely.

Findings: The study showed that non-remote workers exhibit greater vigour, dedication and absorption than those working remotely. The lack of social contact was recognised as the most significant drawback of remote work.

Implications / Recommendations: Compared to standard work, long-term remote work can have a negative impact on individuals' engagement in three dimensions - vigour, dedication and absorption.

Contribution: The research results provide the basis for further exploration of psychosocial aspects of remote work.

Keywords: remote work, COVID-19 pandemic, work engagement, psychosocial aspects. 